\title{
Culture models to define key mediators of cancer matrix remodeling
}

\section{Emily Suzanne Fuller and Viive Maarika Howell *}

Bill Walsh Translational Cancer Research Laboratory, Kolling Institute of Medical Research, Royal North Shore Hospital, University of Sydney, St. Leonards, NSW, Australia

\section{Edited by:}

Elise Kohn, National Cancer Institute, USA

\section{Reviewed by:}

Elise Kohn, National Cancer Institute USA

Ben Davidson, Oslo University

Hospital, Norway

Christina Annunziata, National Cancer Institute, USA

\section{${ }^{*}$ Correspondence:}

Viive Maarika Howell, Bill Walsh

Translational Cancer Research Laboratory, Kolling Institute of

Medical Research, Royal North Shore Hospital, University of Sydney, Level

8, Kolling Building, St Leonards, NSW 2065 Australia

e-mail:viive.howell@sydney.edu.au
High grade serous epithelial ovarian cancer (HG-SOC) is one of the most devastating gynecological cancers affecting women worldwide, with a poor survival rate despite clinical treatment advances. HG-SOC commonly metastasizes within the peritoneal cavity, primarily to the mesothelial cells of the omentum, which regulate an extracellular matrix rich in collagens type I, III, and IV along with laminin, vitronectin, and fibronectin. Cancer cells depend on their ability to penetrate and invade secondary tissue sites to spread, however a detailed understanding of the molecular mechanisms underlying these processes remain largely unknown. Given the high metastatic potential of HG-SOC and the associated poor clinical outcome, it is extremely important to identify the pathways and the components of which that are responsible for the progression of this disease. In vitro methods of recapitulating human disease processes are the critical first step in such investigations. In this context, establishment of an in vitro "tumor-like" micro-environment, such as 3D culture, to study early disease and metastasis of human HG-SOC is an important and highly insightful method. In recent years, many such methods have been established to investigate the adhesion and invasion of human ovarian cancer cell lines. The aim of this review is to summarize recent developments in ovarian cancer culture systems and their use to investigate clinically relevant findings concerning the key players in driving human HG-SOC.

Keywords: high grade serous epithelial ovarian cancer, metastasis, culture models, 3D, synthetic scaffolds
High grade serous epithelial ovarian cancer (HG-SOC) is a devastating disease and the most lethal of the gynecological malignancies. Typically treatment consists of surgical debulking, followed by platinum/taxol chemotherapy regimens $(1,2)$. Treatment fails in up to $70 \%$ of patients, and patients with platinum resistant disease have a median survival of $6-12$ months $(1,3)$. Some success has been observed in clinical trials for the palliative management of ascites accumulation using targeted antibody treatment (4), and while this symptom based therapy is clinically important, disease modifying/halting treatments are lacking. Other treatments have shown varied success, including those that target tumor angiogenesis such as bevacizumab alone or in combination with platinum agents and gemcitabine. Many other approaches have been taken including tyrosine kinase inhibitors, angiopoietin inhibitors, histone deacetylase inhibition, and EGF receptor targeting (5). The role of immune cells and interactions with tumor stroma are under intense investigation and may improve the future prospects for immunotherapy based regimes (5). However, response to treatment varies between patients and therefore, the development of personalized care through discovery of predictive molecular or protein markers becomes imperative for effective disease treatment.

Modeling HG-SOC as closely as possible to human disease to facilitate clinically relevant treatment testing is the "holy-grail" in research. A plethora of immortalized ovarian cancer cells and in vitro and in vivo model systems that utilize these cell lines have been described. Early disease events are arguably the most therapeutically relevant targets of preventative treatments and here, we discuss recently used model systems to identify pathways involved in the development of invasive malignancy.

\section{ESTABLISHED EPITHELIAL OVARIAN CANCER CELL LINES AS MODEL SYSTEMS: A CONTROVERSIAL CHOICE}

High grade serous epithelial ovarian cancer has long been thought to arise from the epithelial layer surrounding the ovary $(6,7)$. However, studies point to a different site of origin, the secretory cells of the fallopian tube fimbria. This highlights the lack of understanding of the histogenesis and molecular signature of this heterogeneous disease (8-14). Anglesio et al. suggested that the biomarker and molecular signatures of ovarian cancer cell lines may be a more accurate and relevant way of grouping "histotypes" over previously determined histological subtypes (15). However, discrepancies between the molecular profile of ovarian cancer cell lines and the tumor types they model have been identified. In fact, these profiles show more similarity between the cell lines themselves, despite differing tissues of origin $(8,16)$. Further, these reports have raised doubt on the use of a number highly cited ovarian cancer cell lines as models of clinically relevant HGSOC, in particular A2780 and SKOV3 $(8,15)$. Cancer cell lines derived from patients who have undergone treatment will represent a population of cells that is intrinsically different from that of the original tumor due to the development of resistance. However, it has been suggested that cell lines derived from untreated tumors are enriched for resistant cells with up-regulation of multi 
drug resistance associated genes via activation of stress responses during the primary culture process (16).

Immortalized normal ovarian epithelial cells and normal fallopian epithelial cells are increasingly being used to model early stages of cancer development $(10,11,17-21)$. While the use of primary cancer cell cultures avoids issues associated with multiple passages (16), this is a labor intensive method, and differences between individual primary cultures leading to lack of reproducibility, may be a significant confounder. Immortalized cell lines offer the advantage of increased stable survival over longer periods in culture and can be manipulated to include many genetic alterations to mimic the disease of interest. Studies using immortalized cells derived from non-transformed normal human fallopian epithelial secretory cells, along with the induction of relevant genetic alterations, have been shown to successfully model human high grade serous cancer biology $(10,11,19)$. The use of virally induced immortalization of cells is common; however this may also induce unappreciated effects on tumor development and virally induced tumor initiation is irrelevant to the pathogenesis of ovarian cancer. Non-viral methods using shRNA technology have also successfully targeted relevant genetic factors resulting in transformed cells (11).

Along with the method of cell line derivation, site of origin, and continuous passaging, culture conditions (monolayer, various 3D culture models, organ-like culture models) are also significant effectors of the characteristics of established ovarian cancer cell lines $(8,15,16,22)$. These issues are inherently difficult to address and there is likely no ideal way to completely control for all these changes. To date, particular HG-SOC cell lines have not been reported as being more relevant to $3 \mathrm{D}$ culture compared to $2 \mathrm{D}$ culture systems. SKOV3 and A2780 are the most commonly cited but may not be the best representations of HG-SOC with their use in $3 \mathrm{D}$ likely reflecting their popularity in $2 \mathrm{D}$ systems. Therefore at this stage there are no specific criteria for cell line selection for $3 \mathrm{D}$ systems and progression from $2 \mathrm{D}$ to $3 \mathrm{D}$ experiments with the same cell line can be a useful strategy. However, consistent use at a low passage number, of an appropriate cell line to model HG-SOC (via histological and molecular markers) is extremely important.

\section{IN VITRO CULTURE MODEL SYSTEMS OF HGSEOC 2D VERSUS 3D CULTURE METHODS}

Although it is well known that culturing cancer cell lines can drastically alter their genetic characteristics over multiple passages immortalized cancer cell lines remain the gold standard in cancer research and pre-clinical drug testing (22). This is largely because these cell lines display a consistent and relatively homogeneous phenotype over long periods of time, notwithstanding reports of minor side populations with cancer stem-like characteristics in some cell lines $(23,24)$. Evidence is accumulating that culturing these cells in $3 \mathrm{D}$ matrices is far more representative of disease than traditional 2D systems, as they provide structurally similar conditions for cell growth encompassing the ability to manipulate oxygen and growth factor/cytokine gradients as well as the material properties of the matrix $(22,25-30)$.

Common methods for assessing ovarian cancer cell proliferation/migration/invasion have included 2D culture growth studies, "scratch" wound healing assays, and penetration through transwell inserts. Scratch wound assays are relatively easy to set up, and very cheap to run and there are now many options for tracking and quantitating cell growth and migration, including the MetaMorph $^{\mathrm{TM}}$ and Incucyte ${ }^{\mathrm{TM}}$ real-time Imaging systems (31). Migration assays through transwell inserts are more expensive and do not allow for real-time monitoring. Microfluidic assays have the advantage that cells can be grown in controlled chemotactic gradients (31). However, these systems have not to date been utilized widely for ovarian cancer cell culture studies. Cell spreading assays, in which a plastic culture surface is coated with various extracellular matrix (ECM) components (fibronectin or collagen type I) and cells are allowed to spread under serum free conditions for a short period of time, have been used to assess migration of ovarian cancer cells (32). While these methods may provide some useful information regarding the characteristics of certain cancer cell lines and their responses to stimuli (drug treatment, signaling molecules), they lack a 3D micro-environment to accurately mimic pathophysiological conditions. 3D environments containing relevant structural proteins (collagens, laminin, elastin) (Figure 1A), as well as defined tissue organization appropriate to site of tumor growth in vivo, are important considerations for recapitulating tumor cell behavior (Figure 1B).

Spread of ovarian cancer cells is complex with cells responding to stimuli from neighboring cells and ECM components and their ability to invade connective tissue is crucial for successful metastasis. In the absence of a requirement for ECM interactions and matrix degradation, 2D systems primarily evaluate the motility of cells, rather than a true invasive barrier removal (29). Care must also be taken when interpreting results based on incomplete $3 \mathrm{D}$ representations of a bona fide tumor/metastatic site ECM. For example, only a partial understanding of the involvement of proteases/MMPs in the spread and invasion of ovarian cancer cells can be drawn from experiments using matrices that lack structural properties of a relevant ECM. For example, matrigel is substantially less cross-linked and differs in overall composition compared to many tissues $(29,31,33)$.

Omental models have been used, in which a primary culture of fibroblasts is grown in 2D with a confluent layer of mesothelial cells grown on top before fluorescently labeled ovarian cancer calls are seeded on a final layer to form a "mock" peritoneal environment. Invasion is typically measured by fluorescent microscopy after the cell layers are cultured in transwell inserts placed over growth promoting media. (26,34-36). These models provide a more accurate representation of the tissue structure encountered by tumor cells, by supplying a barrier to test "metastatic" invasion of cells in presence of other cells such as fibroblasts that are important to disease processes. However, primary tumor development and the "metastatic cascade" are highly complex processes, and the 2D platforms that are currently used do not typify pathways involved, likely contributing to the unsuccessful translation of findings into in vivo systems and eventual failure of many treatments under clinical trial (37).

\section{NATURAL VERSUS SYNTHETIC 3D PLATFORMS}

The importance of recapitulating tumor ECM in model systems was highlighted by Infanger and others in their review (25). These authors stated that interactions between tumor cells and their 




surrounding micro-environment are as pivotal to tumorigenicity as oncogenic mutation (25). Normal homeostatic process and tissue structural properties control the dormancy required after malignant transformation of epithelial cells and when these pathways fail, along with the presence of certain genetic mutations, cells grow uncontrollably and tumors develop (25). Currently, there is a definite lack of studies that evaluate the combined effect of cell-cell, cell-ECM interactions as well as biochemical, biomechanical, and the specific processes that occur during the metastatic processes of ovarian cancer $(25,38)$.

Hydrogels, such as Matrigel, are commonly used for in vitro studies of ovarian cancer cell growth and invasion $(29,32,39)$. Other substrates such as collagen gels (40), polyhydroxyethylmethacrylate coated plastics (22), algimatrix, and geltrex are also used to model ECM (16). Natural alternatives include human amniotic membranes (HAM) and chick chorioallantoic membranes (CAM). 3D culture systems incorporating amniotic membranes have been used to assess the spreading and invasive capacities of ovarian cancer cells. These offer the advantage of a physiologically relevant tissue barrier for assessment of cell behavior (41-43). Limitations of these materials are the batch to batch variation, presence of confounding growth factors and other biological components whose effects on culturing experiments are not well known $(25,44)$. Other non-biological considerations in these model systems, which to date have been largely ignored, are the tissue structural properties as well as 
gradients of oxygen tension and effects from external physical stimuli (compression, shear stress) $(25,41)$.

Semi-synthetic matrices such as polyethylene glycol (PEG), hyaluronan, alginate-based, and peptide-based (Puramatrix ${ }^{\mathrm{TM}}$ ) hydrogels are amenable to experimental determination of matrix stiffness and integration of different binding sites and protease cleavage sites $(31,45)$. Matrix stiffness has been shown to influence endothelial cell behavior independently of matrix molecular composition, highlighting the relevance of matrix material properties in tumor modeling (46). PEG based hydrogels have been used to investigate the role of proteases in the migration of fibroblasts (47) and more recently to investigate cell-ECM interactions and drug resistance of epithelial ovarian cancer cells (48).

Semi-synthetic or synthetic matrices offer the greatest levels of experimental reproducibility due to the control that investigators have in the makeup of the ECM. The study by Loessner et al. is, to date, the most relevant study using a synthetic 3D scaffold to comprehensively investigate ovarian cancer cell growth and response to drugs in an anisotropic biomimetic hydrogel (48). This method enables combination of designed binding sites, protease substrates, other proteins including growth factors and an easily adjustable matrix stiffness. Cells seeded uniformly in the liquid scaffold precursor are exposed to similar levels of biomechanical and biochemical stimuli in all directions (48).

While these models are highly relevant, the addition of other cell types found in the cancer micro-environment (stromal cells, immune cells) would make these models more complete. The immune response has been shown to be clinically relevant in ovarian cancer. Traditionally, immune-cancer cell interactions have been studied in $2 \mathrm{D}$ cultures by the addition of immune components or immune stimulatory factors. The establishment of a physiologically relevant tumor micro-environment would enable all cells present (cancer, stromal, immune) to phenotypically resemble those found in disease (49-52). This would create a unique and powerful in vitro situation for testing the effects of different immune components and inflammatory responses relevant to disease. For example, TNF- $\beta$ is known to effect ECM stability, and could therefore influence the capacity of tumor cells to migrate and invade (53). A biologically relevant in vitro representation of a tumor is also central for accurately testing drug efficacy, as the interaction of different cell types contributes to the drug response (54). Various 3D models (spheroid cultures, scaffold based 3D cultures, organotypic cultures) would be amenable to the addition of immune factors/cytokines, and although not yet in development, $3 \mathrm{D}$ co-culture of many cell types found in ovarian cancer including immune cells should be possible $(55,56)$.

Heterotypic culture to simulate the micro-environment of ovarian cancer has been shown to be a promising and representative method for investigating stromal-epithelial interactions during disease (57). It has been suggested that modeling ovarian cancer by using 3D cultures of fallopian tube secretory epithelial cells would be more relevant to early stage HG-SOC (58). Combining synthetic matrices, in heterotypic culture with the relevant cells that drive the initiation processes of disease to investigate potential therapeutic targets, would be ideal. A collaborative effort between the NIH, FDA, and the Defense Advanced Research Projects Agency has been instigated to develop and refine methods for functional organ microphysiological systems aimed at drug screening (59). These may also have potential for use in cancer biology. For example, a human liver-like model has been developed to study breast cancer metastases (60). It is possible that such models may, in the future, be adapted to investigate metastases to the liver in ovarian cancer. Table 1 summarizes some of the factors to consider when choosing a method to model cancer cell growth.

3D modeling of early stage ovarian cancer, which the aforementioned systems aim to achieve, may be the most relevant for identifying potential targets for disease modifying therapies. The second stage of disease involves the spread of ovarian cancer cells from the primary tumor into the peritoneal space. Experiments to capture the behavior of ovarian cancer cells during metastasis focus on anchorage-independent models of cell migration (68-71). Multicellular aggregate, or spheroid formation is critical for shedding of cancer cells from the primary tumor, and it has recently been shown that the culture of ovarian cancer cells as spheroids in a biomimetic ECM, recapitulates the metastatic niche (72). Further, the biomechanical environment of the peritoneal space plays an important role on cancer cell behavior and spread, and so incorporation of physiological fluid mechanics are appropriate in these systems $(41,69)$. While the development of oxygen tension gradients limits the size of the multicellular spheroids in culture; it mimics the structure of solid tumors and the potential development of necrotic cores $(73,74)$. This representation of the physiological micro-environment is relevant and appropriate for the screening of drugs, as penetration into the tumor/spheroid is very different to $2 \mathrm{D}$ systems and consequently, the response will also be very different (75). A recent study by Jaeger et al. describes the development of a 3D culture system incorporating an oxygen permeable polymer and micro pillars, to mimic gas delivery via vessels (76). This system offers the potential of larger growth of organotypic models and more realistically represents vascularized tumors in vivo.

Tissue chips are a relatively new area of research aimed at incorporating as many components as possible to recapitulate the living tissue and study biological responses to many factors in concert $(77,78)$. Tissue chips allow the modeling of organ systems in a highly functional and controlled manner. They can incorporate many components relevant to tumor biology such as various 3D matrix components and hydrogels. These systems have the potential as tools for measuring metastatic potential, response to various growth stimulators or inhibitors, immune interactions, and drug responses. However, optimization of parameters such as endpoint data collection is still required in order to use these systems for complex tumor modeling $(77,78)$.

\section{CONCLUSION AND FUTURE PERSPECTIVES}

Many advances have been made in recent years in the development of representative $3 \mathrm{D}$ models to mimic ovarian cancer relevant to human HG-SOC. However, these systems are still limited and none to date combine all factors, biomechanical, and biological, to create a complete experimental culture system. This is compounded by recent controversy regarding the molecular characterization of HG-SOC cell lines, with several that are commonly used for research, being shown to be non-representative of this 
Table 1 | Summary of factors contributing to the choice of model system for ovarian cancer cell culture.

\begin{tabular}{|c|c|c|c|c|}
\hline & $\begin{array}{l}\text { Natural/ } \\
\text { synthetic }\end{array}$ & $\begin{array}{l}\text { Control of ECM } \\
\text { composition }\end{array}$ & $\begin{array}{l}\text { Relevance to } \\
\text { in vivo tumor }\end{array}$ & Comments/reference \\
\hline \multicolumn{5}{|l|}{ COMPONENT/SYSTEM } \\
\hline Human amniotic membrane (HAM) & Natural & Low & Medium & $\begin{array}{l}\text { Physiologically relevant/provides ECM barrier/batch to batch } \\
\text { variation high (42) }\end{array}$ \\
\hline Chick chorioallantoic membrane (CAM) & Natural & Low & Medium & $\begin{array}{l}\text { Physiologically relevant/provides ECM barrier/batch to batch } \\
\text { variation high (43) }\end{array}$ \\
\hline $\begin{array}{l}\text { Collagen gel (acid extracted type } 1 \\
\text { collagen from rat tail) }\end{array}$ & Synthetic & Medium & Low & $\begin{array}{l}\text { Variable ECM stiffness/invasion assessment (binding } \\
\text { sites/matrix interaction) }(61,62)\end{array}$ \\
\hline $\begin{array}{l}\text { Matrigel (derived from mouse EHS cell } \\
\text { secretions; laminin, collagen IV, } \\
\text { enactin, various growth factors) }\end{array}$ & Synthetic & Medium & Low & $\begin{array}{l}\text { Widely used (migration and invasion)/batch variation } \\
\text { high/irrelevant matrix composition/properties }(29,31,33)\end{array}$ \\
\hline $\begin{array}{l}\text { Alginate/peptide-based (inert } \\
\text { polysaccharide, } \beta \text { - } d \text {-mannuronic acid, } \\
\alpha \text {-l-guluronic acid, calcium ions) }\end{array}$ & Synthetic & High & Medium & $\begin{array}{l}\text { Variable ECM stiffness/defined components/binding } \\
\text { sites/matrix interaction }(63,64)\end{array}$ \\
\hline $\begin{array}{l}\text { PEG (various cross-linked polyethylene } \\
\text { glycol hydrogels) coasted plastics }\end{array}$ & Synthetic & High & Medium & $\begin{array}{l}\text { Variable ECM stiffness/defined components/binding } \\
\text { sites/matrix interaction/enzymatically degradable }(31,65)\end{array}$ \\
\hline Heterotypic/organotypic culture & Synthetic & High & High & $\begin{array}{l}\text { Relevant micro-environment/cell interaction/combine with } \\
\text { synthetic } \operatorname{ECM}(64,66)\end{array}$ \\
\hline Spheroid culture & Synthetic & High & Medium & $\begin{array}{l}\text { Biologically relevant/cell-cell interactions/combine with } \\
\text { synthetic } \operatorname{ECM}(31,58,67)\end{array}$ \\
\hline
\end{tabular}

grade of ovarian cancer. It has become clear that when modeling the micro-environment, it is particularly important to create an ECM that closely mimics that relevant to ovarian cancer, and so considerations of the origin of the cell line are important. For example, an ECM relevant to a primary tumor derived cell line may be different from that of a cell line derived from ascites. Likewise, generation of an appropriate ECM for early disease modeling may have different requirements for epithelial cells derived from the fallopian tube to those derived from the ovarian surface. Only through a comprehensive understanding of physiological tumor behavior will it be possible to identify key players in tumor progression, whether these are ECM proteins (MMPs, TIMPs), immune regulators or cytokines or upstream genetic changes in the cancer cells themselves.

While the sophisticated 3D culture models developed in the last few years have circumvented many problems associated with traditional methods, the use of these systems is still in its infancy in part due to the complex nature, cost, and specialized equipment that is often required. Thus these methods are not yet amenable for highthroughput experimentation and pre-clinical testing. However, technological progress in the coming years will hopefully reduce these limitations and see the widespread use of high-throughput screening using $3 \mathrm{D}$ culture systems that accurately recapitulate the tumor micro-environment.

\section{REFERENCES}

1. Saladino E, Fleres F, Irato S, Famulari C, Macrí A. The role of cytoreductive surgery and hyperthermic intraperitoneal chemotherapy in the treatment of ovarian cancer relapse. Updates Surg (2013) 65(4):265-70. doi:10.1007/s13304013-0229-9

2. van Altena AM, van den Akker PA, de Hullu JA, Ottevanger PB, Aalders AL, Gerritse R, et al. Efficacy of a regional network for ovarian cancer care. Obstet Gynecol (2013) 122(3):668-75. doi:10.1097/AOG.0b013e3182a054ee

3. Armstrong DK, Bundy B, Wenzel L, Huang HQ, Baergen R, Lele S, et al. Intraperitoneal cisplatin and paclitaxel in ovarian cancer. N Engl J Med (2006) 354(1):34-43. doi:10.1056/NEJMoa052985

4. Eskander RN, Tewari KS. Epithelial cell-adhesion molecule-directed trifunctional antibody immunotherapy for symptom management of advanced ovarian cancer. Clin Pharmacol (2013) 5(Suppl 1):55-61. doi:10.2147/CPAA.S45885

5. Baumann $\mathrm{KH}$, Wagner U, du Bois A. The changing landscape of therapeutic strategies for recurrent ovarian cancer. Future Oncol (2012) 8(9):1135-47. doi:10.2217/fon.12.112

6. Jiang F, Saunders BO, Haller E, Livingston S, Nicosia SV, Bai W. Conditionally immortal ovarian cell lines for investigating the influence of ovarian stroma on the estrogen sensitivity and tumorigenicity of ovarian surface epithelial cells. In vitro Cell Dev Biol Anim (2003) 39(7):304-12. doi:10.1290/1543-706X(2003) $039<0304$ :CIOCLF>2.0.CO;2

7. Nicosia SV, Nicosia RF. Neoplasms of ovarian mesothelium. In: Azar HA, Azar HA, editors. Pathology of Human Neoplasms. New York: Raven Press (1988). p. 435-86.

8. Domcke S, Sinha R, Levine DA, Sander C, Schultz N. Evaluating cell lines as tumour models by comparison of genomic profiles. Nat Commun (2013) 4:2126. doi:10.1038/ncomms3126

9. Jones PM, Drapkin R. Modeling high-grade serous carcinoma: how converging insights into pathogenesis and genetics are driving better experimental platforms. Front Oncol (2013) 3:217. doi:10.3389/fonc.2013.00217

10. Karst AM, Drapkin R. Primary culture and immortalization of human fallopian tube secretory epithelial cells. Nat Protoc (2012) 7(9):1755-64. doi:10.1038/ nprot.2012.097

11. Karst AM, Levanon K, Drapkin R. Modeling high-grade serous ovarian carcinogenesis from the fallopian tube. Proc Natl Acad Sci US A (2011) 108(18):7547-52. doi:10.1073/pnas.1017300108 
12. Kim J, Coffey DM, Creighton CJ, Yu Z, Hawkins SM, Matzuk MM. High-grade serous ovarian cancer arises from fallopian tube in a mouse model. Proc Natl Acad Sci U S A (2012) 109(10):3921-6. doi:10.1073/pnas.1117135109

13. Kurman RJ, Shih Ie M. The origin and pathogenesis of epithelial ovarian cancer: a proposed unifying theory. Am J Surg Pathol (2010) 34(3):433-43. doi:10.1097/PAS.0b013e3181cf3d79

14. Rescigno P, Cerillo I, Ruocco R, Condello C, De Placido S, Pensabene M. New hypothesis on pathogenesis of ovarian cancer lead to future tailored approaches. Biomed Res Int (2013) 2013:852839. doi:10.1155/2013/852839

15. Anglesio MS, Wiegand KC, Melnyk N, Chow C, Salamanca C, Prentice LM, et al. Type-specific cell line models for type-specific ovarian cancer research. PLoS One (2013) 8(9):e72162. doi:10.1371/journal.pone.0072162

16. Gillet JP, Calcagno AM, Varma S, Marino M, Green LJ, Vora MI, et al. Redefining the relevance of established cancer cell lines to the study of mechanisms of clinical anti-cancer drug resistance. Proc Natl Acad Sci U S A (2011) 108(46):18708-13. doi:10.1073/pnas.1111840108

17. Archibald KM, Kulbe H, Kwong J, Chakravarty P, Temple J, Chaplin T, et al. Sequential genetic change at the TP53 and chemokine receptor CXCR4 locus during transformation of human ovarian surface epithelium. Oncogene (2012) 31(48):4987-95. doi:10.1038/onc.2011.653

18. Davies BR, Steele IA, Edmondson RJ, Zwolinski SA, Saretzki G, von Zglinicki T, et al. Immortalisation of human ovarian surface epithelium with telomerase and temperature-sensitive SV40 large T antigen. Exp Cell Res (2003) 288(2):390-402. doi:10.1016/S0014-4827(03)00218-0

19. Fotheringham S, Levanon K, Drapkin R. Ex vivo culture of primary human fallopian tube epithelial cells. J Vis $\operatorname{Exp}$ (2011) (51):e2728. doi:10.3791/2728

20. Lawrenson K, Sproul D, Grun B, Notaridou M, Benjamin E, Jacobs IJ, et al. Modelling genetic and clinical heterogeneity in epithelial ovarian cancers. Carcinogenesis (2011) 32(10):1540-9. doi:10.1093/carcin/bgr140

21. Maeda T, Tashiro H, Katabuchi H, Begum M, Ohtake H, Kiyono T, et al. Establishment of an immortalised human ovarian surface epithelial cell line without chromosomal instability. Br J Cancer (2005) 93(1):116-23. doi:10.1038/sj.bjc. 6602662

22. Lee JM, Mhawech-Fauceglia P, Lee N, Parsanian LC, Lin YG, Gayther SA et al. A three-dimensional microenvironment alters protein expression and chemosensitivity of epithelial ovarian cancer cells in vitro. Lab Invest (2013) 93(5):528-42. doi:10.1038/labinvest.2013.41

23. Rizzo S, Hersey JM, Mellor P, Dai W, Santos-Silva A, Liber D, et al. Ovarian cancer stem cell-like side populations are enriched following chemotherapy and overexpress EZH2. Mol Cancer Ther (2011) 10(2):325-35. doi:10.1158/15357163.MCT-10-0788

24. Zeimet AG, Reimer D, Sopper S, Boesch M, Martowicz A, Roessler J, et al. Ovarian cancer stem cells. Neoplasma (2012) 59(6):747-55. doi:10.4149/neo_ 2012_094

25. Infanger DW, Lynch ME, Fischbach C. Engineered culture models for studies of tumor-microenvironment interactions. Annu Rev Biomed Eng (2013) 15:29-53. doi:10.1146/annurev-bioeng-071811-150028

26. Kenny HA, Lengyel E. MMP-2 functions as an early response protein in ovarian cancer metastasis. Cell Cycle (2009) 8(5):683-8. doi:10.4161/cc.8.5.7703

27. Kwon Y, Cukierman E, Godwin AK. Differential expressions of adhesive molecules and proteases define mechanisms of ovarian tumor cell matrix penetration/invasion. PLoS One (2011) 6(4):e18872. doi:10.1371/journal.pone.0018872

28. Martell RE, Brooks DG, Wang Y, Wilcoxen K. Discovery of novel drugs for promising targets. Clin Ther (2013) 35(9):1271-81. doi:10.1016/j.clinthera. 2013.08.005

29. Sodek KL, Brown TJ, Ringuette MJ. Collagen I but not Matrigel matrices provide an MMP-dependent barrier to ovarian cancer cell penetration. BMC Cancer (2008) 8:223. doi:10.1186/1471-2407-8-223

30. Sodek KL, Murphy KJ, Brown TJ, Ringuette MJ. Cell-cell and cell-matrix dynamics in intraperitoneal cancer metastasis. Cancer Metastasis Rev (2012) 31(1-2):397-414. doi:10.1007/s10555-012-9351-2

31. Pouliot N, Pearson HB, Burrows A. Investigating metastasis using in vitro platforms. In: Madame Curie Bioscience Database [Internet]. (2013). Austin, TX: Landes Bioscience; Available from: http://www.ncbi.nlm.nih.gov/books/ NBK100379/

32. Yagi H, Yotsumoto F, Miyamoto S. Heparin-binding epidermal growth factorlike growth factor promotes transcoelomic metastasis in ovarian cancer through epithelial-mesenchymal transition. Mol Cancer Ther (2008) 7(10):3441-51. doi:10.1158/1535-7163.MCT-08-0417
33. Kleinman HK, Martin GR. Matrigel: basement membrane matrix with biological activity. Semin Cancer Biol (2005) 15(5):378-86. doi:10.1016/j.semcancer. 2005.05.004

34. Cai J, Tang H, Xu L, Wang X, Yang C, Ruan S, et al. Fibroblasts in omentum activated by tumor cells promote ovarian cancer growth, adhesion and invasiveness. Carcinogenesis (2012) 33(1):20-9. doi:10.1093/carcin/bgr230

35. Kenny HA, Kaur S, Coussens LM, Lengyel E. The initial steps of ovarian cancer cell metastasis are mediated by MMP-2 cleavage of vitronectin and fibronectin. J Clin Invest (2008) 118(4):1367-79. doi:10.1172/JCI33775

36. Kenny HA, Krausz T, Yamada SD, Lengyel E. Use of a novel 3D culture model to elucidate the role of mesothelial cells, fibroblasts and extra-cellular matrices on adhesion and invasion of ovarian cancer cells to the omentum. Int J Cancer (2007) 121(7):1463-72. doi:10.1002/ijc.22874

37. Kusuma N, Anderson RL, Pouliot N. Laminin alpha5-derived peptides modulate the properties of metastatic breast tumour cells. Clin Exp Metastasis (2011) 28(8):909-21. doi:10.1007/s10585-011-9422-8

38. Bignotti E, Tassi RA, Calza S, Ravaggi A, Romani C, Rossi E, et al. Differential gene expression profiles between tumor biopsies and short-term primary cultures of ovarian serous carcinomas: identification of novel molecular biomarkers for early diagnosis and therapy. Gynecol Oncol (2006) 103(2):405-16. doi:10.1016/j.ygyno.2006.03.056

39. Kaimal R, Aljumaily R, Tressel SL, Pradhan RV, Covic L, Kuliopulos A, et al. Selective blockade of matrix metalloprotease-14 with a monoclonal antibody abrogates invasion, angiogenesis, and tumor growth in ovarian cancer. Cancer Res (2013) 73(8):2457-67. doi:10.1158/0008-5472.CAN-12- 1426

40. Moss NM, Liu Y, Johnson JJ, Debiase P, Jones J, Hudson LG, et al. Epidermal growth factor receptor-mediated membrane type 1 matrix metalloproteinase endocytosis regulates the transition between invasive versus expansive growth of ovarian carcinoma cells in three-dimensional collagen. Mol Cancer Res (2009) 7(6):809-20. doi:10.1158/1541-7786.MCR-08-0571

41. Avraham-Chakim L, Elad D, Zaretsky U, Kloog Y, Jaffa A, Grisaru D. Fluid-flow induced wall shear stress and epithelial ovarian cancer peritoneal spreading. PLoS One (2013) 8(4):e60965. doi:10.1371/journal.pone.0060965

42. Touboul C, Lis R, Al Farsi H, Raynaud CM, Warfa M, Althawadi H, et al. Mesenchymal stem cells enhance ovarian cancer cell infiltration through IL6 secretion in an amniochorionic membrane based 3D model. J Transl Med (2013) 11:28. doi:10.1186/1479-5876-11-28

43. de Vrij J, Dautzenberg IJ, van den Hengel SK, Magnusson MK, Uil TG, Cramer SJ, et al. A cathepsin-cleavage site between the adenovirus capsid protein IX and a tumor-targeting ligand improves targeted transduction. Gene Ther (2012) 19(9):899-906. doi:10.1038/gt.2011.162

44. Vukicevic S, Kleinman HK, Luyten FP, Roberts AB, Roche NS, Reddi AH. Identification of multiple active growth factors in basement membrane Matrigel suggests caution in interpretation of cellular activity related to extracellular matrix components. Exp Cell Res (1992) 202(1):1-8. doi:10.1016/00144827(92)90397-Q

45. Yang Z, Zhao X. A 3D model of ovarian cancer cell lines on peptide nanofiber scaffold to explore the cell-scaffold interaction and chemotherapeutic resistance of anticancer drugs. Int J Nanomedicine (2011) 6:303-10. doi:10.2147/ IJN.S15279

46. Mason BN, Starchenko A, Williams RM, Bonassar LJ, Reinhart-King CA. Tuning three-dimensional collagen matrix stiffness independently of collagen concentration modulates endothelial cell behavior. Acta Biomater (2013) 9(1):4635-44. doi:10.1016/j.actbio.2012.08.007

47. Raeber GP, Lutolf MP, Hubbell JA. Molecularly engineered PEG hydrogels: a novel model system for proteolytically mediated cell migration. Biophys J (2005) 89(2):1374-88. doi:10.1529/biophysj.104.050682

48. Loessner D, Stok KS, Lutolf MP, Hutmacher DW, Clements JA, Rizzi SC. Bioengineered 3D platform to explore cell-ECM interactions and drug resistance of epithelial ovarian cancer cells. Biomaterials (2010) 31(32):8494-506. doi:10.1016/j.biomaterials.2010.07.064

49. Azzazene D, Al Thawadi H, Al Farsi H, Besbes S, Geyl C, Mirshahi S, et al. Plasma endothelial protein $\mathrm{C}$ receptor influences innate immune response in ovarian cancer by decreasing the population of natural killer and TH17 helper cells. Int J Oncol (2013) 43(4):1011-8. doi:10.3892/ijo.2013.2021

50. Giuntoli RL II, Webb TJ, Zoso A, Rogers O, Diaz-Montes TP, Bristow RE, et al. Ovarian cancer-associated ascites demonstrates altered immune environment: implications for antitumor immunity. Anticancer Res (2009) 29(8): 2875-84. 
51. Govindaraj C, Scalzo-Inguanti K, Madondo M, Hallo J, Flanagan K, Quinn $\mathrm{M}$, et al. Impaired Thl immunity in ovarian cancer patients is mediated by TNFR2 + Tregs within the tumor microenvironment. Clin Immunol (2013) 149(1):97-110. doi:10.1016/j.clim.2013.07.003

52. Zhang L, Conejo-Garcia JR, Katsaros D, Gimotty PA, Massobrio M, Regnani G, et al. Intratumoral T cells, recurrence, and survival in epithelial ovarian cancer. N Engl J Med (2003) 348(3):203-13. doi:10.1056/NEJMoa020177

53. Yeung TL, Leung CS, Wong KK, Samimi G, Thompson MS, Liu J, et al. TGFbeta modulates ovarian cancer invasion by upregulating CAF-derived versican in the tumor microenvironment. Cancer Res (2013) 73(16):5016-28. doi:10.1158/0008-5472.CAN-13-0023

54. Celli JP, Rizvi I, Blanden AR, Massodi I, Glidden MD, Pogue BW, et al. An imaging-based platform for high-content, quantitative evaluation of therapeutic response in 3D tumour models. Sci Rep (2014) 4:3751. doi:10.1038/srep03751

55. Yamada KM, Cukierman E. Modeling tissue morphogenesis and cancer in 3D. Cell (2007) 130(4):601-10. doi:10.1016/j.cell.2007.08.006

56. Hirschhaeuser F, Menne H, Dittfeld C, West J, Mueller-Klieser W, KunzSchughart LA. Multicellular tumor spheroids: an underestimated tool is catching up again. J Biotechnol (2010) 148(1):3-15. doi:10.1016/j.jbiotec.2010. 01.012

57. Lawrenson K, Grun B, Gayther SA. Heterotypic three-dimensional in vitro modeling of stromal-epithelial interactions during ovarian cancer initiation and progression. J Vis Exp (2012) (66):e4206. doi:10.3791/4206

58. Lawrenson K, Notaridou M, Lee N, Benjamin E, Jacobs IJ, Jones C, et al. In vitro three-dimensional modeling of fallopian tube secretory epithelial cells. BMC Cell Biol (2013) 14(1):43. doi:10.1186/1471-2121-14-43

59. Sutherland ML, Fabre KM, Tagle DA. The National Institutes of Health Microphysiological Systems Program focuses on a critical challenge in the drug discovery pipeline. Stem Cell Res Ther (2013) 4(Suppl 1). doi:10.1186/scrt361

60. Wheeler SE, Borenstein JT, Clark AM, Ebrahimkhani MR, Fox IJ, Griffith L, et al. All-human microphysical model of metastasis therapy. Stem Cell Res Ther (2013) 4(Suppl 1). doi:10.1186/scrt372

61. Barbolina MV, Liu Y, Gurler H, Kim M, Kajdacsy-Balla AA, Rooper L, et al. Matrix rigidity activates Wnt signaling through down-regulation of Dickkopf-1 protein. J Biol Chem (2013) 288(1):141-51. doi:10.1074/jbc.M112.431411

62. Kennedy A, Dong H, Chen D, Chen WT. Elevation of seprase expression and promotion of an invasive phenotype by collagenous matrices in ovarian tumor cells. Int J Cancer (2009) 124(1):27-35. doi:10.1002/ijc.23871

63. Godugu C, Patel AR, Desai U, Andey T, Sams A, Singh M. AlgiMatrix based 3D cell culture system as an in-vitro tumor model for anticancer studies. PLoS One (2013) 8(1):e53708. doi:10.1371/journal.pone.0053708

64. Lee KY, Mooney DJ. Alginate: properties and biomedical applications. Prog Polym Sci (2012) 37(1):106-26. doi:10.1016/j.progpolymsci.2011.06.003

65. Rizzi SC, Ehrbar M, Halstenberg S, Raeber GP, Schmoekel HG, Hagenmüller $\mathrm{H}$, et al. Recombinant protein-co-PEG networks as cell-adhesive and proteolytically degradable hydrogel matrixes. Part II: biofunctional characteristics. Biomacromolecules (2006) 7(11):3019-29. doi:10.1021/bm060504a

66. Kenny HA, Dogan S, Zillhardt M, K Mitra A, Yamada SD, Krausz T, et al. Organotypic models of metastasis: a three-dimensional culture mimicking the human peritoneum and omentum for the study of the early steps of ovarian cancer metastasis. Cancer Treat Res (2009) 149:335-51. doi:10.1007/978-0-387-980942_16

67. Carduner L, Picot CR, Leroy-Dudal J, Blay L, Kellouche S, Carreiras F. Cell cycle arrest or survival signaling through alphav integrins, activation of PKC and ERK1/2 lead to anoikis resistance of ovarian cancer spheroids. Exp Cell Res (2014) 320(2):329-42. doi:10.1016/j.yexcr.2013.11.011

68. Dong Y, Stephens C, Walpole C, Swedberg JE, Boyle GM, Parsons PG, et al. Paclitaxel resistance and multicellular spheroid formation are induced by kallikreinrelated peptidase 4 in serous ovarian cancer cells in an ascites mimicking microenvironment. PLoS One (2013) 8(2):e57056. doi:10.1371/journal.pone. 0057056

69. Grun B, Benjamin E, Sinclair J, Timms JF, Jacobs IJ, Gayther SA, et al. Threedimensional in vitro cell biology models of ovarian and endometrial cancer. Cell Prolif(2009) 42(2):219-28. doi:10.1111/j.1365-2184.2008.00579.x

70. Soritău O, Tomuleasa CI, Páll E, Virág P, Fischer-Fodor E, Foris V, et al. Enhanced chemoresistance and tumor sphere formation as a laboratory model for peritoneal micrometastasis in epithelial ovarian cancer. Rom J Morphol Embryol (2010) 51(2):259-64.

71. Zietarska M, Maugard CM, Filali-Mouhim A, Alam-Fahmy M, Tonin PN, Provencher DM, et al. Molecular description of a 3D in vitro model for the study of epithelial ovarian cancer (EOC). Mol Carcinog (2007) 46(10):872-85. doi:10.1002/mc.20315

72. Loessner D, Flegg JA, Byrne HM, Clements JA, Hutmacher DW. Growth of confined cancer spheroids: a combined experimental and mathematical modelling approach. Integr Biol (Camb) (2013) 5(3):597-605. doi:10.1039/c3ib20252f

73. Kunz-Schughart LA, Kreutz M, Knuechel R. Multicellular spheroids: a threedimensional in vitro culture system to study tumour biology. Int J Exp Pathol (1998) 79(1):1-23. doi:10.1046/j.1365-2613.1998.00051.x

74. Mueller-Klieser W. Three-dimensional cell cultures: from molecular mechanisms to clinical applications. Am J Physiol (1997) 273(4 Pt 1):C1109-23.

75. Nyga A, Cheema U, Loizidou M. 3D tumour models: novel in vitro approaches to cancer studies. J Cell Commun Signal (2011) 5(3):239-48. doi:10.1007/s12079011-0132-4

76. Jaeger AA, Das CK, Morgan NY, Pursley RH, McQueen PG, Hall MD, et al. Microfabricated polymeric vessel mimetics for 3-D cancer cell culture. Biomaterials (2013) 34(33):8301-13. doi:10.1016/j.biomaterials.2013.07.013

77. Baker M. Tissue models: a living system on a chip. Nature (2011) 471(7340):661-5. doi:10.1038/471661a

78. Young EW. Cells, tissues, and organs on chips: challenges and opportunities for the cancer tumor microenvironment. Integr Biol (Camb) (2013) 5(9):1096-109. doi:10.1039/c3ib40076j

Conflict of Interest Statement: The authors declare that the research was conducted in the absence of any commercial or financial relationships that could be construed as a potential conflict of interest.

Received: 21 January 2014; paper pending published: 16 February 2014; accepted: 11 March 2014; published online: 25 March 2014.

Citation: Fuller ES and Howell VM (2014) Culture models to define key mediators of cancer matrix remodeling. Front. Oncol. 4:57. doi: 10.3389/fonc.2014.00057

This article was submitted to Women's Cancer, a section of the journal Frontiers in Oncology.

Copyright (c) 2014 Fuller and Howell. This is an open-access article distributed under the terms of the Creative Commons Attribution License (CC BY). The use, distribution or reproduction in other forums is permitted, provided the original author (s) or licensor are credited and that the original publication in this journal is cited, in accordance with accepted academic practice. No use, distribution or reproduction is permitted which does not comply with these terms. 